\title{
Feeding, pigmentation, photosynthesis and growth of the mixotrophic dinoflagellate Gyrodinium galatheanum
}

\author{
Aishao Li", Diane K. Stoecker, Jason E. Adolf \\ Horn Point Laboratory, University of Maryland Center for Environmental Science, PO Box 775, Cambridge, \\ Maryland 21613, USA
}

\begin{abstract}
Gyrodinium galatheanum is a photosynthetic, mixotrophic dinoflagellate that is capable of ingesting other protists, including cryptophytes. Ingestion of cryptophycean prey involves formation of a protrusion near the flagellar pores in the sulcus region of the dinoflagellate, by which prey are captured and phagocytized. In phototrophically growing G. galatheanum, a total of 12 chlorophylls and carotenoids are detected using HPLC pigment analysis. In G. galatheanum that had been fed cryptophycean prey for $41 \mathrm{~h}$, traces of pigments that were derived from prey were found. This suggests that ingested prey were not fully digested or that some chloroplasts from prey were retained by the dinoflagellate. G. galatheanum cultured in nutrient-replete medium had net positive growth under phototrophic conditions (i.e. without addition of prey). It could not survive in prolonged darkness even with sufficient food supply, and thus is incapable of strictly heterotrophic growth. Under mixotrophic conditions (i.e. in the light with addition of a saturating concentration of prey), growth rates of $G$. galatheanum were 2 - to 3-fold higher than under strictly phototrophic conditions at the same irradiances. Mixotrophically grown $G$. galatheanum had higher cellular chl a, cell volume, and cellular carbon content than cultures grown without particulate food. Phagotrophy also leads to enhanced photosynthetic performance of $G$. galatheanum due to increased photosynthetic capacity $\left(\mathrm{P}_{\max }{ }_{\text {cell }}\right)$, and/or by increased photosynthetic efficiency $\left(\alpha^{\text {cell }}\right)$, particularly when the cells were grown under low light and/or nutrient-limited conditions. These results indicate that $G$. galatheanum is an obligately phototrophic species and that both photosynthesis and phagotrophy play significant roles in supporting the higher growth rates associated with mixotrophic than with strictly autotrophic growth.
\end{abstract}

KEY WORDS: Dinoflagellate - Gyrodinium galatheanum - Feeding sequence $\cdot$ Mixotrophy Photosynthesis - Phagotrophy - Pigmentation - Growth - Cryptophytes · HPLC

\section{INTRODUCTION}

Photosynthetic dinoflagellates usually have lower growth rates than other algal taxa of similar size (Banse 1982, Tang 1995, 1996). It is believed that the lower growth rates of dinoflagellates are partially due to their low chlorophyll (chl) a to carbon ratio (Chan 1980, Tang 1996) and thus their low photosynthetic capacity.

- Present address: Biology Department, Mail Stop 32, Redfield 332. Woods Hole Oceanographic Institution, Woods Hole, Massachusetts 02543-1049, USA.E-mail: ali@whoi,edu
In most obligately phototrophic algae, dark respiration is not sufficient to provide all the energy needed for maximum growth and part of the energy (i.e. adenosine-5'triphosphate [ATP]) directly comes from photosynthetic reactions (Raven 1984). In photosynthetic dinoflagellates, less of an energy subsidy from photosynthesis is provided to support maximum growth because of the low photosynthetic capacity per unit of biomass (Cullen et al. 1992, Tang 1996). Enhanced growth rates, however, have been observed in several photosynthetic dinoflagellates supplied with either dissolved organic compounds (as reviewed in Gaines \& Elbrächter 1987) or particulate prey (Skovgaard 1996a). 
Many dinoflagellates that are often considered strictly phototrophic are mixotrophic, and most of these are capable of ingesting particulate prey (Schnepf \& Elbrächter 1992, Granéli \& Carlsson 1998, Hansen 1998). Questions of whether or not phagotrophy enhances growth or increases ecological fitness in mixotrophic dinoflagellates largely remain unanswered. Studies of other mixotrophic algal taxa, however, have demonstrated that effects of heterotrophy on growth are diverse and that some species are more heterotrophic than phototrophic. For example, Andersson et al. (1989) reported that the photoautotrophic growth of the nanoflagellate Ochromonas sp. was poor while heterotrophic growth in medium containing bacterial prey was rapid, suggesting that heterotrophy in this species is the primary mode for obtaining energy and for organic carbon acquisition whereas phototrophy may be a strategy for survival when the environment for heterotrophy is poor (i.e. lack of prey). In contrast, the mixotrophic chrysophyte Dinobryon cylindricum appears to be more phototrophic than heterotrophic as this alga cannot grow or survive in continuous darkness even with food (bacteria) (Caron et al. 1993). For mixotrophically growing cultures photosynthesis was the major carbon source. These results led the authors to conclude that heterotrophy in $D$. cylindricum is primarily used to provide growth factors or major inorganic nutrients for photosynthetic growth.

Algal photosynthesis is regulated by various environmental factors, particularly by nutrient availability, temperature, and light intensity (Cullen et al. 1992, Kirk 1994). Since heterotrophy in obligate phototrophs may play a role in supplementing macro-nutrients (i.e. $\mathrm{N}$ and $\mathrm{P}$ ) or essential growth factors for photosynthesis, it is natural to speculate that heterotrophy may change photophysiology so as to enhance photosynthetic performance. However, information on this is lacking.

In this study, we focus on Gyrodinium galatheanum, a photosynthetic dinoflagellate that is capable of ingesting other cells, particularly small cryptophytes. Our previous studies have demonstrated that both $G$. galatheanum and its prey cryptophytes are common members of the estuarine phytoplankton in Chesapeake Bay, USA, and that they often co-occur and can form blooms in surface waters ( $\mathrm{Li}$ et al. unpubl.). Our experimental data have also shown that ingestion of cryptophycean prey is enhanced under high-light and/or nutrient-limiting conditions (Li et al. unpubl.). Although ingestion of prey in field samples and in cultures has been demonstrated, feeding behavior had not been examined. Additionally, it has been reported that the pigment composition in G. galatheanum is different from that of most of other photosynthetic dinoflagellates in that this species possesses $\mathrm{ch}$ l. $c_{3}$ but does not have peridinin (Bjornland \& Tangen 1.979 .
Johnsen \& Sakshaug 1993). It is not clear if ingestion of cryptophycean prey has significant impacts on the pigment composition and photophysiology of G. galatheanum. In the present study, we examine feeding behavior, pigment composition, and photophysiological changes in this dinoflagellate when switched from strictly phototrophic to mixotrophic conditions. We test the hypotheses that $G$. galatheanum is an obligately photosynthetic species and that its photosynthetic capacity and growth rates are enhanced through phagotrophy.

\section{MATERIALS AND METHODS}

Culture of organisms. Gyrodinium galatheanum (strain GE) was isolated from a water sample collected from the mesohaline region of Chesapeake Bay in May 1995. Clonal cuitures of $G$. galathednum were obtained by picking out a single cell using a capillary pipette, repeatedly washing the cell with $10 \mathrm{psu}_{4}$ f/2-Si medium in a well of a 28 well plate containing $3 \mathrm{ml}$ of medium per well. The cryptophycean prey Storeatula major (strain g) used in this study was obtained from Dr T. Kana at Horn Point Laboratory (HPL, Cambridge, MD, USA). Stock cultures of these 2 species were maintained at $20^{\circ} \mathrm{C}$ in $10 \mathrm{psu}, \mathrm{f} / 2$ Si medium (Guillard 1975), with a light regime of $12 \mathrm{~h}$ light: $12 \mathrm{~h}$ dark and a photon irradiance rate of 150 $\mu \mathrm{mol} \mathrm{m} \mathrm{m}^{-2} \mathrm{~s}^{-1}$ (Li et al. 1996).

Microscopic observation of feeding. To study the feeding behavior of Gyrodinium galatheanum, $3 \mathrm{ml}$ of a G. galatheanum stock culture were placed in an Utermohl slide chamber. Approximately $0.1 \mathrm{ml}$ of centrifuged Storeatula major were gently injected into the center of the slide using a micropipette and then a cover slip was placed on top of this chamber. Centrifuged $S$. major were used to obtain a concentrate of prey cells. Feeding processes were observed and documented using an inverted microscope at $1000 \times$ (Zeiss Axioscope) equipped with a Sony video system which was connected to a VCR. Still images were then captured from the tape using Snappy Video Snapshot 3.0, digitized, and enhanced for contrast using MS PowerPoint 97

Pigments measured by HPLC. An experiment was designed to compare the pigment composition of feeding and non-feeding cells of Gyrodinium galatheanum. Stock cultures of $G$. galatheanum were inoculated into 4 polycarbonate bottles, each containing $280 \mathrm{ml}$ of f/2-Si medium, and then acclimated for $4 \mathrm{~d}$ at $20^{\circ} \mathrm{C}$ on a $12 \mathrm{~h}$ light:12 h dark cycle at an irradiance rate of $200 \mu \mathrm{mol}$ photons $\mathrm{m}^{-2} \mathrm{~s}^{-1}$. Stock cultures of Storeatula major were inoculated into 2 polycarbonate bottles, each holding $280 \mathrm{ml}$ of $\mathrm{f} / 2$-Si medium. Accli- 
mation for $S$. major was conducted in the same manner as for $G$. galatheanum. After $4 \mathrm{~d}$ acclimation, a $5 \mathrm{ml}$ aliquot of $S$. major was taken from each of the 2 acclimated cryptophyte cultures, and then added to 2 acclimated G. galatheanum cultures. Cell densities of the added $S$. major and $G$. galatheanum in these replicates were approximately $2.8 \times 10^{3}$ cells $\mathrm{ml}^{-1}$ and $3.6 \times 10^{4}$ cells $\mathrm{ml}^{-1}$, respectively. After $41 \mathrm{~h}$ incubation residual $S$. major prey were not detectable in the 2 replicates. Fifty $\mathrm{ml}$ subsamples were then taken from each incubation bottle, including the 2 replicates of pure $G$ galatheanum, 2 replicates of pure $S$. major, and 2 replicates of the fed $G$. galatheanum cultures. These subsamples were filtered onto Whatman GF/F filters, folded, wrapped in aluminum foil, and stored at $-80^{\circ} \mathrm{C}$. Pigments were extracted in $100 \%$ acetone as described by Van Heukelem et al. (1992, 1994). A $20 \mathrm{ml}$ aliquot was also taken from each bottle for cell counts with a Coulter Multisizer II electronic particle counter. Pigments were analyzed on a Hewlett Packard 1100 series high-performance liquid chromatograph (HPLC) equipped with a photodiode array detector, thermostatted auto-injector and column compartment according to Van Heukelem et al. $(1992,1994)$.

Phototrophic growth and mixotrophic growth measurements. For determination of growth rates of Gyrodinium galatheanum in mono-species cultures (absence of prey) at different light intensities, stock cultures of $G$. galatheanum were inoculated into 27 polycarbonate bottles, each containing $200 \mathrm{ml}$ of $10 \mathrm{psu}, \mathrm{f} / 2$-Si medium. Light treatments were established as dark, 14, 30,60, 100, 200, 300, 550, and $800 \mu \mathrm{mol}$ photons $\mathrm{m}^{-2} \mathrm{~s}^{-1}$. Each of these treatments had 3 replicates. Prior to subsampling, G. galatheanum were allowed to acclimate for $3 \mathrm{~d}$ at $20^{\circ} \mathrm{C}$ at these light regimes on a $12 \mathrm{~h}$ light: $12 \mathrm{~h}$ dark cycle. Twenty ml aliquots were then taken from each replicate at intervals of $24 \mathrm{~h}$ for $5 \mathrm{~d}$. Whenever an aliquot was taken, $20 \mathrm{ml}$ of $\mathrm{f} / 2-\mathrm{Si}$ medium was added back to the replicate. Density of G. galatheanum was then counted using a Coulter Multisizer II electronic particle counter.

For determination of growth and grazing rates of Gyrodinium galatheanum grown in mixotrophic cultures (i.e. with addition of Storeatula major) at different light intensities, stock cultures of $G$. galatheanum were inoculated into 15 polycarbonate bottles, each containing $200 \mathrm{ml}$ of $10 \mathrm{psu}, \mathrm{f} / 2-\mathrm{Si}$ medium. Treatments, each with 3 replicates, were dark, 60, 100, 200, and 800 $\mu \mathrm{mol}$ photons $\mathrm{m}^{-2} \mathrm{~s}^{-1}$ on a $12 \mathrm{~h}$ light: $12 \mathrm{~h}$ dark cycle at $20^{\circ} \mathrm{C}$. During a $3 \mathrm{~d}$ acclimation period, stock cultures of $S$. major were added daily to feed the G. galatheanum. Density of added $S$. major varied during the acclimation period, ranging from approximately 300 cells $\mathrm{ml}^{-1}$ on the first day to $1.5 \times 10^{4}$ cells $\mathrm{ml}^{-1}$ on the third day. The same amount of $S$. major was added to control bot- tles that each contained $200 \mathrm{ml}$ of $10 \mathrm{psu}, \mathrm{f} / 2-\mathrm{Si}$ medium. These control bottles were treated in a similar manner as the treatment bottles. After $3 \mathrm{~d}$ acclimation, sampling commenced with $20 \mathrm{ml}$ aliquots taken from each bottle every $24 \mathrm{~h}$ for $5 \mathrm{~d}$ and fixed with $1 \%$ glutaraldehyde. S. major density in each treatment bottle was adjusted to $\sim 1.5 \times 10^{4}$ cells $\mathrm{ml}^{-1}$ before each $24 \mathrm{~h}$ incubation period by adding prey grown under the same light conditions or by diluting the experimental cultures with $\mathrm{f} / 2$-Si medium. In each treatment bottle, the prey density was at least 3 times higher than the saturation density $\left(\sim 5 \times 10^{3} \mathrm{~S}\right.$. major cells $\mathrm{ml}^{-1}$ at a light intensity of $\sim 1800 \mu \mathrm{mol}$ photons $\mathrm{m}^{-2} \mathrm{~s}^{-1}$ ) (Li et al. 1996) and the predator:prey density ratio was approximately $1: 4$.

For microscopic analysis, slides were made using the fixed samples as previously described by Li et al (1996). The slides were stored frozen at $-20^{\circ} \mathrm{C}$ and subsequently examined with epifluorescence microscopy (Zeiss filter set 487709; BP450-490 exciter filter, FT 510 dichromatic beam splitter, and LP520 barrier filter) Cell density data were used to calculate growth rates of Gyrodinium galatheanum in phototrophic and mixotrophic treatments based on the method described by Skovgaard (1996a). The instantaneous growth rate, $\mu(G$. gal), for G. galatheanum in phototrophic and mixotrophic cultures was determined in steps of $24 \mathrm{~h}$ due to daily dilution of the samples and calculated as:

$$
\mu(G . g a l)=\left(\ln N t_{1}-\ln N t_{0}\right) /\left(t_{1}-t_{0}\right)
$$

where $N t_{1}$ and $N t_{0}$ are the cell density of $G$. galatheanum at the start $\left(t_{0}\right)$ and the end $\left(t_{1}\right)$ of the $24 \mathrm{~h}$ incubation period, respectively. The growth rates for the prey Storeatula major in experimental bottles as well as in control bottles were calculated as:

$$
\mu(C r y)=\left(\ln M t_{1}-\ln M t_{0}\right) /\left(t_{1}-t_{0}\right)
$$

where $\mu(C r y)$ is growth rate of $S$. major and $M t_{1}$ and $M t_{0}$ are the cell density of $S$. major in control bottles at the start $\left(t_{0}\right)$ and the end $\left(t_{1}\right)$ of each $24 \mathrm{~h}$ incubation period, respectively. The ingestion rates for $G$. galatheanum feeding on $S$. major in experimental bottles were determined from the reduction in prey density over $24 \mathrm{~h}$ periods. Estimates of the ingestion rates, I were based on the description by Skovgaard (1996a), and modified as follows:

$$
\begin{gathered}
\mathrm{d} M / \mathrm{d} t=\mu(C r y) \times M-I \times N \\
\mathrm{~d} N / \mathrm{d} t=\mu(G . g a l) \times N
\end{gathered}
$$

where $M$ is prey ( $S$. major) density in the experimental bottle at time $t$, and $N$ is predator ( $G$. galatheanum) density in the same bottle at the same time. This method assumes that the predator grew exponentially with a rate of $\mu(G, g a l)$ while the prey grew exponentially with a rate of $\mu(\mathrm{Cry})$ in both the control and treatment bottles. The 
mortality of prey in the experimental bottles is assumed to be due to ingestion $(I \times N)$. Using a program provided by Skovgaard (1996a), $I$ was iteratively calculated with time on a computer, allowing steps of 1 h (Hansen \& Nielsen 1997).

Photosynthesis measurements. Two sets of ${ }^{14} \mathrm{C}$-uptake experiments were conducted. The first experiment was designed to examine the photosynthetic performance for Gyrodinium galatheanum growing under different conditions (i.e. nutrient deplete vs nutrient replete, as well as low light vs high light), and to compare changes in photosynthetic parameters when $G$. galatheanum which had been grown under different conditions were fed Storeatula major. Prior to inoculation, stock cultures of $G$. galatheanum were concentrated and washed with 10 psu, nutrient-free seawater using repeated reverse filtration through $8 \mu \mathrm{m}$ pore size membrane filters. Twenty $\mathrm{ml}$ of these washed, concentrated G. galatheanum cultures were then inoculated into 12 polycarbonate bottles, each containing $270 \mathrm{ml}$ of $10 \mathrm{psu}$, nutrient-free medium. By controlling light intensity and addition or omission of inorganic nutrients (nitrate and phosphate), 4 treatments, each with 3 replicates, were established as follows: (1) high-light high-nutrient; (2) high-light low-nutrient; (3) low-light high-nutrient; and (4) lowlight low-nutrient. Samples in high-light treatments received a photon flux density (PFD) of $200 \mu \mathrm{mol}$ photons $\mathrm{m}^{-2} \mathrm{~s}^{-1}$ while samples in low-light treatments received $60 \mu \mathrm{mol}$ photons $\mathrm{m}^{-2} \mathrm{~s}^{-1}$. Samples in highnutrient treatments grew in medium with $883 \mu \mathrm{M}$ of $\mathrm{NO}_{3}{ }^{-}$and $36 \mu \mathrm{M}$ of $\mathrm{PO}_{4}{ }^{3-}$ while samples in low-nutrient treatments were in nutrient-deplete conditions (undetectable concentrations of $\mathrm{NO}_{3}{ }^{-}$and $\mathrm{PO}_{4}{ }^{3-}$ ). These treatment bottles were acclimated under the assigned conditions for $3 \mathrm{~d}$.

After acclimation, $160 \mathrm{ml}$ of subsample was taken from each replicate and subjected to a 'clean-up' procedure. The 'clean-up' procedure on this pre-feeding subsample was set as a control process since the same procedure was later used to remove the residual prey in after-feeding samples. The 'cleaned' subsample was then taken for cell count, chi a measurements, and photosynthesis measurements. The rest of the sample in each replicate bottle was then fed with Storeatula major, which had been rinsed in nutrient-free medium and passed through an $8 \mu \mathrm{m}$ membrane filter. The added S. major density was approximately $6 \times 10^{3}$ cells $\mathrm{ml}^{-1}$. Gyrodinium galatheanum in each replicate was allowed to feed on the prey for $24 \mathrm{~h}$. A 'clean-up' procedure for these fed samples was then used. In this process, $110 \mathrm{ml}$ of incubated sample from each replicate was gently reduced to $-25 \mathrm{ml}$ and then returmed to $150 \mathrm{ml}$ using the original medium for that treatment. The sample was carried through 6 additional washes, each representing a 1:6 dilution, and then brought to $100 \mathrm{ml}$. Three $\mathrm{ml}$ of subsample were then taken from the manipulated sample to check for residual prey in the medium. By this filtration process, the density of residual prey in the medium was diluted $>4.5 \times 10^{4}$ times and $>99 \%$ of residual prey in the medium was removed. The entire filtration process required approximately 2 h to be completed. G. galatheanum appeared to be unharmed by the cleaning procedures as there was no detectable change in swimming patterns compared to unmanipulated cultures. Aliquots were taken from these 'cleaned' samples for cell counts, chl a determination, and photosynthesis measurements.

Density of Gyrodinium galatheanum was determined using a Coulter Multisizer II electronic particle counter. Chl a was measured spectrophotometrically according to Parsons et al. (1984). Photosynthetic rates of non-fed (before feeding) and fed (after feeding) G. galatheanum were measured at the treatment temperdiuse $\left(20^{\circ} \mathrm{C}\right)$ in temperature-controlled photosynthetrons using the ${ }^{14} \mathrm{C}$-uptake method, essentially as described by Lewis \& Smith (1983). An aliquot of the sample was spiked with $\mathrm{NaH}^{14} \mathrm{CO}_{3}{ }^{-}$(ICN Chemicals) to give a final activity of approximately $2 \times 10^{6}$ disintegrations per minute (DPM) $\mathrm{ml}^{-1}$ and then dispensed in $2 \mathrm{ml}$ aliquots among $8 \times 7 \mathrm{ml}$ scintillation vials (Kimble) in a photosynthetron. Each vial received a different light level (calibrated after each experiment using a Biospherical Instruments QSL-101 probe). Duplicate samples were used for determination of total ${ }^{14} \mathrm{C}$ activity $(200 \mu \mathrm{l}$ of spiked sample added directly to $4.5 \mathrm{ml}$ of scintillation cocktail [Ecolume]). Following a $60 \mathrm{~min}$ incubation with 8 irradiance levels and 1 dark control per replicate, unincorporated ${ }^{14} \mathrm{C}$ was removed by adding $5 \mathrm{ml}$ of $5 \%$ glacial acetic acid in methanol to each vial and evaporating to dryness at $60^{\circ} \mathrm{C}$ in a fume hood. One ml distilled water and $4 \mathrm{ml}$ scintillation cocktail were then added and the samples counted on a liquid scintillation counter.

The second photosynthesis experiment was designed to compare contributions of photosynthesis and phagotrophy to Gyrodinium galatheanum growth under strictly phototrophic and mixotrophic conditions. In this experiment, stock cultures of $G$. galatheanum were inoculated into 6 polycarbonate bottles, each containing $400 \mathrm{ml}$ of $10 \mathrm{psu}, \mathrm{f} / 2-\mathrm{Si}$ medium. Three of these were to be feeding treatment bottles and the others were to be non-feeding control bottles. Stock cultures of Storeatula major were inoculated into 3 polycarbonate bottles, each holding $400 \mathrm{ml}$ of $10 \mathrm{psu}, \mathrm{f} / 2-\mathrm{Si}$ medium. These 3 cryptophyte cultures were to be used as a food supply and to determine $S$. major growth during the feeding trials. All of these inoculations were acclimated for $4 \mathrm{~d}$ at $20^{\circ} \mathrm{C}$ and at an irradiance of $200 \mu \mathrm{mol}$ photons $\mathrm{m}^{-2} \mathrm{~s}^{-1}$ on a $12 \mathrm{~h}$ light:12 h dark cycle. Sub- 
samples were then taken from each of these bottles for cell counts, CHN analyses, and photosynthesis measurements. Cultures of $S$. major were then added daily to the 3 feeding treatment bottles for $2 \mathrm{~d}$. During the feeding incubation, $S$. major density in the feeding treatment bottles was adjusted to $\sim 1.5 \times 10^{4}$ cells $\mathrm{ml}^{-1}$ before each $24 \mathrm{~h}$ period by adding prey grown under the experimental conditions or by diluting with $\mathrm{f} / 2-\mathrm{Si}$ medium. In each feeding treatment bottle, the prey density was at least 3 times higher than the saturation density $\left(-5 \times 10^{3}\right.$ prey cells $\mathrm{mi}^{-1}$ at a light intensity of $\sim 1800 \mu \mathrm{mol}$ photons $\mathrm{m}^{-2} \mathrm{~s}^{-1}$ ) (Li et al. 1996) and the predator:prey density ratio was approximately 1:10. During the feeding trial period, a $20 \mathrm{ml}$ aliquot was taken from each treatment, control, and cryptophyte growth bottle every $24 \mathrm{~h}$ and fixed with $1 \%$ glutaraldehyde. Slides for cell counting by epifluorescence microscopy were made using previously described techniques (Li et al. 1996). Data on cell densities were used to estimate growth rates of $G$. galatheanum in phototrophic (i.e. mono-species) cultures and in mixotrophic cultures (i.e. G. galatheanum fed S. major in the light). Ingestion rates of $S$. major by $G$. galatheanum in the feeding treatment bottles incubated at $200 \mu \mathrm{mol}$ photons $\mathrm{m}^{-2} \mathrm{~s}^{-1}$ were calculated as described earlier.

After addition of prey for $24 \mathrm{~h}$, subsamples were taken from each replicate for photosynthesis measurements. Samples for photosynthesis measurements were 'cleaned' and processed in a similar way as in the first photosynthesis experiment, except that a 40 min incubation with at least 12 irradiance levels was used for each replicate. Also, after the ${ }^{14} \mathrm{C}$ incubation, samples were killed with $200 \mu$ formalin, and unincorporated ${ }^{14} \mathrm{C}$ was removed by adding $0.5 \mathrm{ml}$ of $6 \mathrm{~N} \mathrm{HCl}$ to each vial followed by ovemight incubation on an orbital shaker (Bellco) at room temperature. The ${ }^{14} \mathrm{C}$ uptake in these samples was then measured on a liquid scintillation counter

Photosynthesis (P) versus irradiance (I) data from the first photosynthesis experiment were fit with a linear regression in order to determine $\alpha^{\text {cell }}$ and $\alpha^{\text {chl }}$. This was done because the irradiance levels used in this experiment did not fully saturate photosynthesis, making the use of any saturating function inappropriate. These $P$ versus I data were truncated at $200 \mu \mathrm{mol}$ photon $\mathrm{m}^{-2} \mathrm{~s}^{-1}$ to improve the fit of the linear regression (mean $r^{2}$ of linear regressions $=0.72$ ).

$P$ versus I data for the second photosynthesis experiment were fit with the following model according to Jassby \& Platt (1976) using SigmaPlot 4.0 (SPSS ${ }^{\circledast}$ Software):

$$
\mathrm{P}^{\text {cell }}=\mathrm{P}_{\max }{ }^{\text {cell }} \times \tanh \left(\alpha^{\text {cell }} \times \mathrm{I} / \mathrm{P}_{\max }{ }^{\text {cell }}\right)
$$

where $\mathrm{P}_{\max }$ cell is cell-specific photosynthetic capacity, $\alpha^{\text {cell }}$ is the initial slope of the P-I curve, and I is irradi- ance. $I_{k}\left(=P_{\max }{ }^{\text {cell }} / \alpha^{\text {cell }}\right)$, the irradiance at which photosynthesis is first saturated, was calculated using parameter values derived from Eq. (5). A correction procedure was applied to calculate Gyrodinium galatheanum cell-specific photosynthetic rate ( $\mathrm{P}^{c e l l}$ ) in the second photosynthesis experiment because the separation procedure used to remove prey after the feeding period was not completely successful. The procedure used (1) cell-specific P versus I curves determined on triplicate Storeatula major cultures grown under the same conditions of light, temperature and cell density as was used during the feeding experiment, and (2) measurements of the number of $S$. major cells in each of the mixed cultures. These data were used to calculate G. galatheanum cell-specific photosynthesis at each $\mathrm{P}$ versus I curve light level according to the following equation:

$$
\mathrm{P}^{G \text { gal }}=\left[\mathrm{P}^{\text {vial }}-\left(\mathrm{P}^{\mathrm{Cr} y} \times\left(\text { cryptophyte } \mathrm{ml}^{-1}\right)\right]\right.
$$$$
\text { (G. galatheanum } \mathrm{ml}^{-1} \text { ) }
$$

where $\mathrm{P}^{\text {G.gal }}$ and $\mathrm{P}^{C r y}$ represent the cell-specific photosynthetic rate at a given irradiance level for either $G$. galatheanum or the cryptophyte prey, respectively. Pvial represents the total photosynthesis per ml measured at the same irradiance level in the vial containing the mixed culture of G. galatheanum and cryptophyte prey. An analysis was performed to determine the sensitivity of estimates of $\mathrm{P}^{G \text { gal }}$ obtained by this procedure to variability in the inputs of $\mathrm{P}^{C r y}$ and cryptophytes per $\mathrm{ml}$.

\section{RESULTS}

\section{Feeding behavior}

Gyrodinium galatheanum engulfed whole cells of Storeatula major. A representative feeding sequence is shown in Fig. 1. After addition of the cryptophyte prey, most of the G. galatheanum cells increased their swimming speed, and some of them began to swim around the prey. In most cases of feeding, the G. galatheanum cell formed a protrusion near the flagellar pores in the sulcus region, and the protrusion attached to the prey (Fig. 1A). After the protrusion contacted the prey cell, phagocytosis began (Fig. 1B). On occasion, a thin filament was observed to project from the extending sulcus region in the epicone, and the filament was used to capture and thereafter draw the prey cell to the surface of the dinoflagellate where the protrusion formed. After firmly capturing prey, G. galatheanum usually stopped swimming and began to draw the whole prey cell through the protrusion into the dinoflagellate cell. During the feeding process, a 'feeding gap' appeared to form along the cingulum near the flagellar pores and a pair of 'lip-like' protrusions was observed (Fig. 1C, D, 


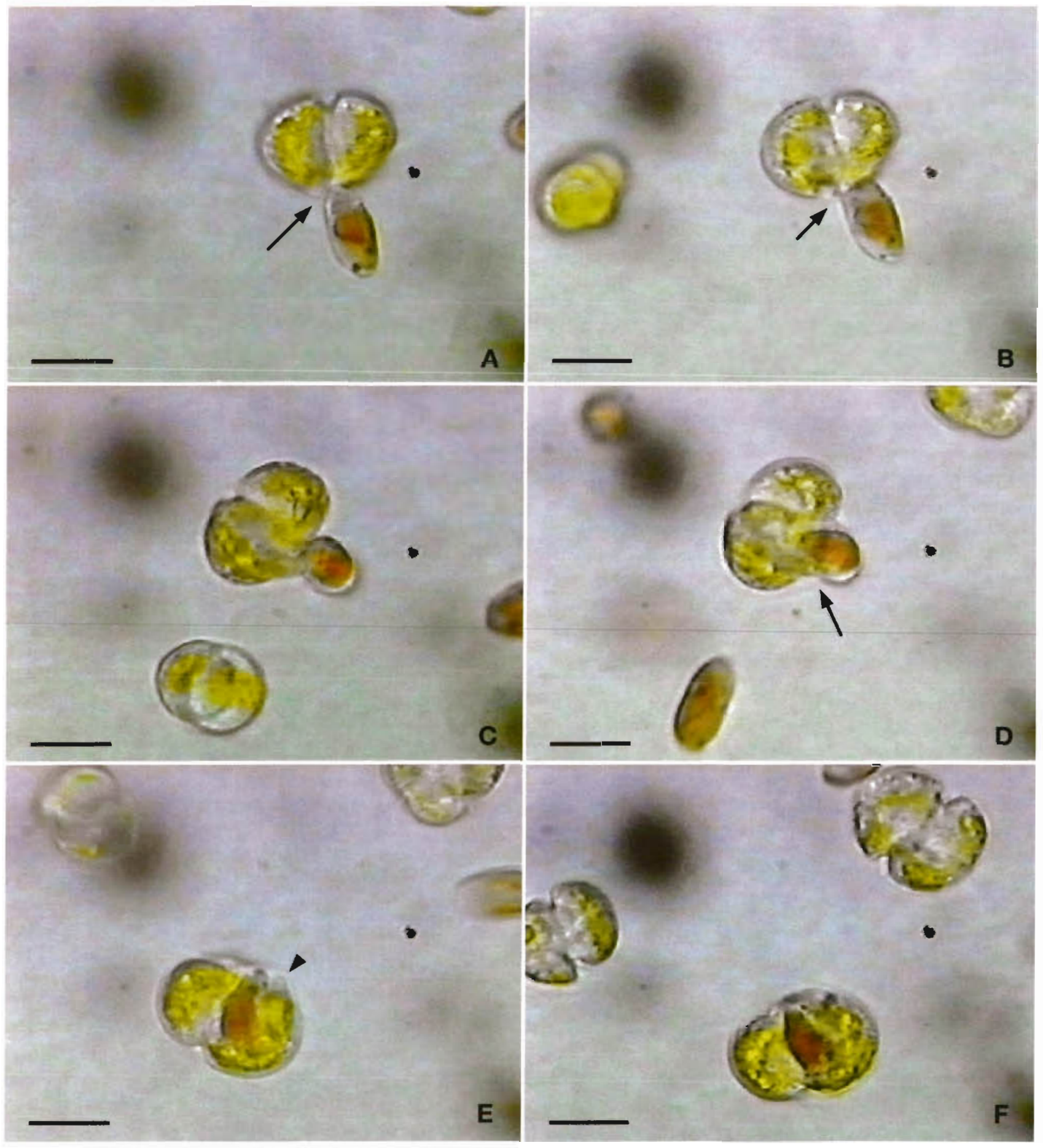

Fig. 1 Video sequence of Gyrodinium galatheanum engulfing Storeatula major (A) G. galatheanum captures prey cell with a protrusion formed near the sulcus region. (B) The protrusion expands and begins to draw the prey cell into the dinoflagellate. (C) The prey cell is distorted during engulfment. (D) The protrusion gradually moves laterally along the prey surface, which causes further engulfment of the prey cell. (E) The prey cell is fully engulfed, but the 'feeding gap' is still open. (F) Engulfment of the prey cell is finished, and the dinoflagellate is ready to swim away. Scale bars: $10 \mu \mathrm{m}$. Arrows indicate the feeding apparatus (protrusion) while arrowhead indicates a 'lip-like protrusion' in the feeding gap 
E). As ingestion proceeded, the cell volume of $G$. galatheanum gradually increased. Engulfment of prey usually took 2 to $3 \mathrm{~min}$ at room temperature $\left(-20^{\circ} \mathrm{C}\right)$. When ingestion was complete, the $G$. galatheanum cell resumed swimming and was able to phagocytize another prey cell.

\section{Pigment composition}

Phototrophically and mixotrophically grown Gyrodinium galatheanum, as well as the cryptophyte prey Storeatula major, were evaluated for pigment composition using HPLC (Table 1). In strictly phototrophically grown $G$. galatheanum, 12 pigments were detected, which included chl $c_{3}$, chl $c_{2}, 19^{\prime}$ BOF (19' -butanoyloxyfucoxanthin), fucoxanthin, 19'HOF (19'-hexanoyloxyfucoxanthin), diadinoxanthin, diatoxanthin, zeaxanthin on occasion, gyroxanthin-diester, chl a, $\beta$-carotene, and 1 pigment that has not been identified (Table 1). Five pigments were detected in $S$. major (Table 1). Among these, alloxanthin, crocoxanthin and $\alpha$-carotene were pigments found in $S$. major but not found in strictly phototrophically grown $G$. galatheanum. Alloxanthin, crocoxanthin and $\alpha$-carotene were also found in mixotrophically grown G. galatheanum (Table 1), although these pigments accounted for only a small proportion of the total pigments (Table 1). Since only a few prey were fed to $G$. galatheanum in the mixed cultures (predator:prey ratio was 16:1) at the initiation of the experiment, there was no quantitative difference in the dominant pigments (e.g. chl $a$ and fucoxanthin) between mixotrophically grown and phototrophically grown $G$. galatheanum after a $41 \mathrm{~h}$ incubation period (Mann-Whitney rank sum test, p > 0.05). Correspondingly, there was no significant difference between phototrophic growth rate $\left(0.24 \mathrm{~d}^{-1}, \mathrm{SE}=0.02\right)$ and mixotrophic growth rate $\left(0.24 \mathrm{~d}^{-1}, \mathrm{SE}=0.03\right)$ in this experiment (Mann-Whitney rank sum test, $\mathrm{p}>0.05$ ).

\section{Phototrophic and mixotrophic growth of Gyrodinium galatheanum}

Changes in the growth rates of Gyrodinium galatheanum with irradiance in phototrophic and in foodsaturated mixotrophic cultures followed hyperbolic tangent patterns (Fig. 2A). The estimated lowest irradiance that supported net growth in phototrophic cultures (compensation irradiance) was approximately $10 \mu \mathrm{mol}$ photons $\mathrm{m}^{-2} \mathrm{~s}^{-1}$. At an irradiance of $384 \mu \mathrm{mol}$ photons $\mathrm{m}^{-2} \mathrm{~s}^{-1}$, G. galatheanum reached its maximum phototrophic growth rate $\left(\mu_{\max }\right)$ of $0.32 \mathrm{~d}^{-1}(\mathrm{SE}=0.02)$. In contrast, the estimated lowest irradiance that supported net growth in mixotrophic cultures was approximately $4 \mu \mathrm{mol}$ photons $\mathrm{m}^{-2} \mathrm{~s}^{-1}$, and G. galatheanum in mixotrophic cultures reached its $\mu_{\max }$ of $0.94 \mathrm{~d}^{-1}$ $\left(\mathrm{SE}=0.06\right.$ ) at an irradiance of $372 \mu \mathrm{mol}$ photons $\mathrm{m}^{-2} \mathrm{~s}^{-1}$ $\left(\mathrm{I}_{\mu_{\max }}\right)$. Ingestion rates of $G$. galatheanum growing in food-saturated mixotrophic cultures increased hyperbolically with irradiance (Fig. 2B). The estimated maximum ingestion rate was $0.33(\mathrm{SE}=0.02)$ Storeatula ma-

Table 1. Pigment composition of phototrophically and mixotrophically grown Gyrodinium galatheanum and of Storeatula major. Mixotrophically grown G. galatheanum were allowed to feed on $S$. major for $41 \mathrm{~h}$. Sample size $=2$. Numbers in parentheses represent 1 standard error. Growth rates for phototrophically and mixotrophically grown G. galatheanum were $0.237 \pm 0.0327$ $\left(\mathrm{d}^{-1}\right)$ and $0.238 \pm 0.0201\left(\mathrm{~d}^{-1}\right)$, respectively.,+-- : pigment was present or absent but quantitative data were not available. 19'BOF: 19'-butanoyloxyfucoxanthin, 19'HOF: 19'-hexanoyloxyfucoxanthin

\begin{tabular}{|c|c|c|c|c|c|}
\hline \multirow[t]{3}{*}{ Pigment } & \multicolumn{4}{|c|}{ G. galatheanum (pg cell ${ }^{-1}$ ) } & \multirow[t]{3}{*}{ S. major (pg cell $\left.{ }^{-1}\right)$} \\
\hline & \multicolumn{2}{|c|}{ Phototrophic cells } & \multicolumn{2}{|c|}{ Mixotrophic cells } & \\
\hline & $T_{0}$ & $T_{41}$ & $T_{0}$ & $I_{41}$ & \\
\hline $\mathrm{Chl} c_{3}$ & $0.06(0.004)$ & $0.06(0.002)$ & $0.06(0.009)$ & $0.07(0.009)$ & 0 \\
\hline $\mathrm{Chl} c_{2}$ & $0.23(0.010)$ & $0.21(0.009)$ & $0.23(0.001)$ & $0.25(0.010)$ & $0.19(0.002)$ \\
\hline $19^{\prime} \mathrm{BOF}$ & $0.16(0.008)$ & $0.13(0.007)$ & $0.15(0.012)$ & $0.13(0.002)$ & 0 \\
\hline Fucoxanthin & $0.33(0.010)$ & $0.36(0.017)$ & $0.32(0.029)$ & $0.39(0.021)$ & 0 \\
\hline $19^{\prime} \mathrm{HOF}$ & $0.26(0.016)$ & $0.22(0.007)$ & $0.25(0.02)$ & $0.24(0.011)$ & 0 \\
\hline Diadinoxanthin & $0.14(0.002)$ & $0.11(0.003)$ & $0.19(0.041)$ & $0.11(0.013)$ & 0 \\
\hline Alloxanthin & 0 & 0 & 0 & $0.06(0.041)$ & $0.72(0.013)$ \\
\hline Diatoxanthin & $0.20(0.015\}$ & $0.16(0.009)$ & $0.11(0.034)$ & $0.14(0.030)$ & 0 \\
\hline Zeaxanthin & + & + & + & + & - \\
\hline Gyroxanthin-diester & + & + & + & + & - \\
\hline Unknown & + & + & + & + & - \\
\hline Crocoxanthin & - & - & - & + & + \\
\hline Chl a & $1.65(0.020)$ & $1.57(0.073)$ & $1.61(0.090)$ & $1.90(0.046)$ & $2.41(0.032)$ \\
\hline$\alpha$-carotene & 0 & 0 & 0 & $0.02(0.010)$ & $0.16(0.003)$ \\
\hline$\beta$-carotene & $0.03(0.002)$ & $0.03(0.001)$ & $0.03(0.002)$ & $0.03(0.001)$ & 0 \\
\hline
\end{tabular}



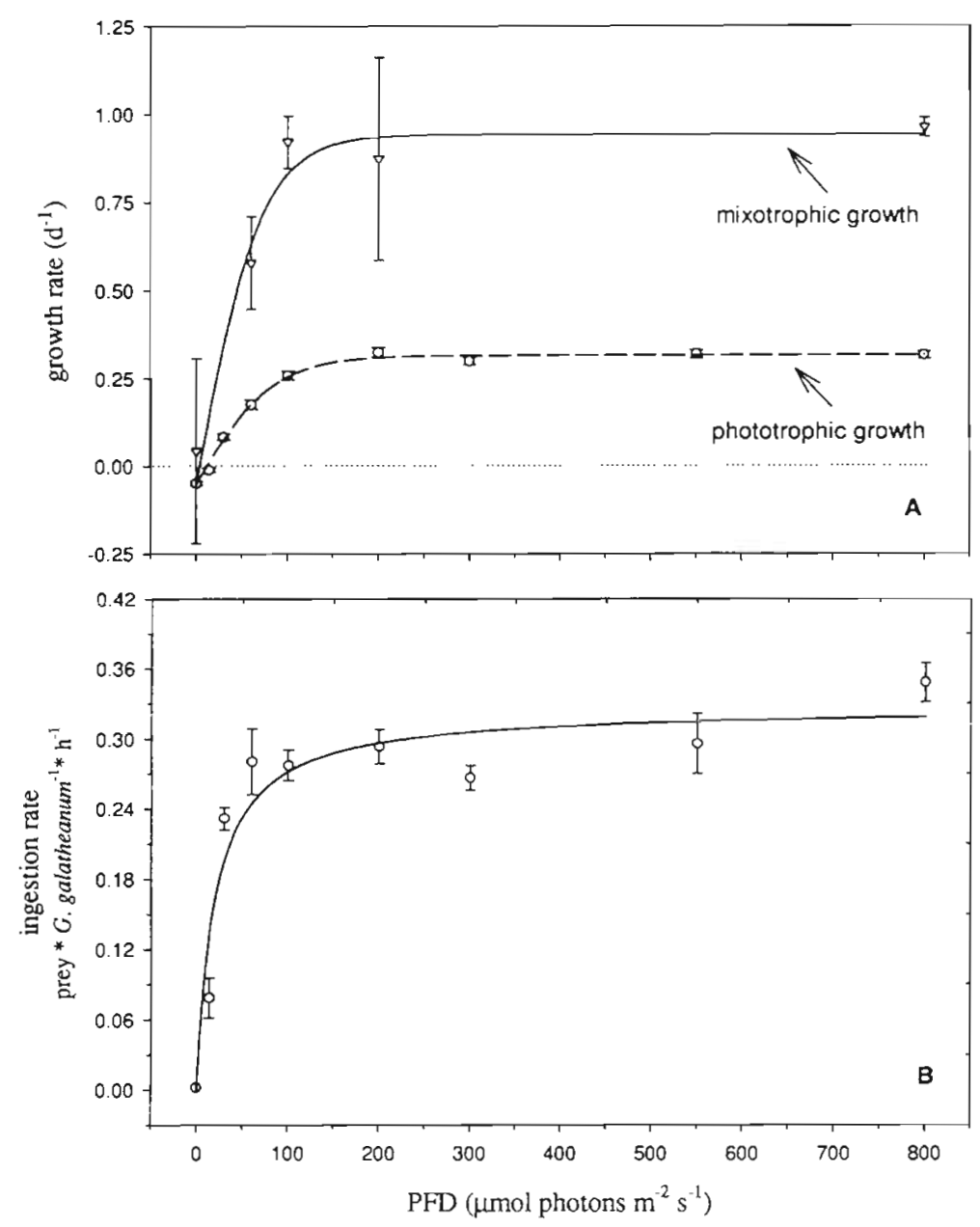

Fig. 2. Gyrodinium galatheanum. (A) Growth rate as a function of irradiance. G. galatheanum was grown phototrophically in mono-specific cultures $(\nabla)$ and mixotrophically in cultures with daily addition of cryptophycean prey Storeatula major $(0) . \mathrm{n}=3$. The curves are fit with the following hyperbolic tangent equations: for mixotrophically growing cultures $y=0.993 \times \tanh (0.014 \times \times / 0.993)-0.05, \mathrm{r}^{2}=0.97$, and $\mathrm{p}<0.01$, and for phototrophically growing cultures $y=0.3662 \times \tanh (0.0044 \times$ $x / 0.3662)-0.05, r^{2}=0.99$, and $p<0.01$. (B) Ingestion rate of $G$. galatheanum in food-saturated cultures as a function of irradiance. The curve is fit with the hyperbolic equation: $y=0.33 \times x /(20.02+x), r^{2}=0.91$, and $\mathrm{p}<0.01$ Error bars indicate $\pm 1 \mathrm{SE}, \mathrm{n}=3$. PFD: photon flux density

could not be estimated. The photosynthetic efficiency $\left(\alpha^{\text {cell }}\right)$, however, was estimated from the linear portion of the photosynthesis rate $(P)$ versus irradiance (I) curve. Our results revealed that after feeding on Storeatula major for $24 \mathrm{~h}$, Gyrodinium galatheanum significantly increased its $\alpha^{\text {cell }}$ in the highlight and low-nutrient treatment (HL). Increases in $\alpha^{\text {cell }}$ after feeding were also observed in the low-light and high-nutrient (LH) and low-light and low-nutrient (LL) treatments, although these changes were not statistically significant. Correspondingly, increases in cellular chl a content and cell volume after feeding were observed in these treatments (Table 2). In the high-light and high-nutrient $(\mathrm{HH})$ treatment, a significant decrease in cellular chl a content was observed ( $t$-test, $p<0.05$ ). A large increase in chlorophyll-specific photosynthetic efficiency $\left(\alpha^{\text {chl }}\right)$ was observed following feeding in the $\mathrm{HH}$ treatment, but the change was not statistically significant (Table 2). In the other treatments, $\alpha^{\text {chl }}$ decreased after feeding (Table 2) although this decrease was only statistically significant in the LL treatment ( $t$-test, $\mathrm{p}<0.05$ ) (Table 2).

In the second photosynthesis experiment, because of the incomplete separation of Gyrodinium galatheanum from residual cryptophycean prey, a correction procedure was applied to calculate the cell-specific photosynthesis for G. galatheanum $\left(\mathrm{P}_{\max }{ }^{G . g a l}\right)$. A sensitivity analysis was performed to test the effects of variability in the input parameters $\mathrm{P}_{\max }{ }^{\mathrm{Cr}}$ and cryptophytes $\mathrm{ml}^{-1}$ on our estimate of $\mathrm{P}_{\max }{ }^{\text {G.gal }}$ obtained by using this correction procedure (Fig. 3). Using the mean values for these 2 inputs, we calculated a $113 \%$ increase in $\mathrm{P}_{\max }{ }^{G . g a l}$ after feeding. An increase in either (or both) of these input parameters will decrease our calculated estimate of $P_{\max } G$ gal, therefore the sensitivity

jor dinoflagellate ${ }^{-1} \mathrm{~h}^{-1}$, and the estimated half saturating irradiance for feeding was approximately $20 \mu \mathrm{mol}$ photons $\mathrm{m}^{-2} \mathrm{~s}^{-1}$. Extremely low ingestion rates of $9.39 \times$ $10^{-3}\left(\mathrm{SE}=4.72 \times 10^{-4}\right)$ S. major dinoflagellate ${ }^{-1} \mathrm{~h}^{-1}$ were detected in the absence of light (Fig. 2B).

\section{Photosynthesis in feeding and non-feeding cells}

In the first photosynthesis experiment, most of the irradiance levels in the photosynthetron were less than saturating and thus photosynthetic capacity $\left(\mathrm{P}_{\max }{ }^{\text {cell }}\right)$ analysis was used to determine the effect of a simultaneous increase of 2 standard deviations (SD) in both parameters on the estimate of $P_{\max }{ }^{G g a}$. This resulted in an approximate $30 \%$ decrease in our estimate of $P_{\max }{ }^{G g a l}$ for cultures that had been fed cryptophytes. This reduced estimate of $P_{\max }{ }^{G \text { gal }}$ still represents a 55\% increase in $P_{\max }{ }^{G g a l}$ for feeding cultures compared to the unfed samples. From this analysis we conclude that variation in the input parameters $\mathrm{P}_{\max }{ }^{\mathrm{cry}}$ and/or cryptophytes $\mathrm{ml}^{-1}$ are unlikely to explain the observed increase in $\mathrm{P}_{\max }{ }^{G . y o l}$ calculated for feeding cultures of $G$. galatheanum, and that the technique we used to 
Table 2. Gyrodinium galatheanum. Comparison of photosynthesis efficiency $\alpha$, cell volume and cellular chl $a$ before and after feeding for cells grown at different irradiances and under different inorganic nutrient conditions (photosynthesis Expt 1). Treatments in this experiment were $\mathrm{HH}$ : high-light and high-nutrient, HL: high-light and low-nutrient, LH: low-light and high-nutrient, and LL: low-light and low-nutrient. Treatments in high light received irradiance of $200 \mu \mathrm{mol}$ photons $\mathrm{m}^{-2} \mathrm{~s}^{-1}$ while treatments in low light received $60 \mu \mathrm{mol}$ photons $\mathrm{m}^{-2} \mathrm{~s}^{-1}$ Treatments in high nutrient were grown in $\mathrm{f} / 2$-Si media while treatments in low nutrient were grown in nutrient-deplete media (undetectable concentrations of $\mathrm{NO}_{3}^{-}$and $\mathrm{PO}_{4}^{3-}$ ). Within the same treatment, having the same letter (a) between 'before' and 'after' indicates there is not a significant difference between these groups $(t$-test, $p>0.05$ ), while having a different letter (a and b) between 'before' and 'after' indicates that there is a significant difference

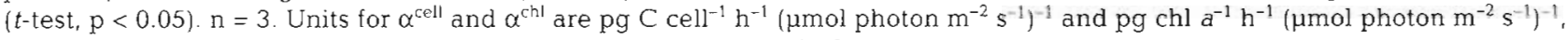
respectively

\begin{tabular}{|c|c|c|c|c|c|c|c|c|}
\hline \multirow{3}{*}{ Parameter } & \multicolumn{8}{|c|}{ Treatment } \\
\hline & \multicolumn{2}{|c|}{$\mathrm{HH}$} & \multicolumn{2}{|c|}{$\mathrm{HL}$} & \multicolumn{2}{|c|}{$\mathrm{LH}$} & \multicolumn{2}{|c|}{ LL } \\
\hline & Before & After & Before & After & Before & After & Before & After \\
\hline$\alpha^{\text {cell }}$ & $0.11(0.01)^{a}$ & $0.10(0.01)^{\mathrm{a}}$ & $0.03(0.01)^{d}$ & $0.06(0.01)^{\mathrm{b}}$ & $0.08(0.01)^{\mathrm{d}}$ & $0.12(0.02)^{\mathrm{a}}$ & $0.07(0.01)^{\mathrm{d}}$ & $0.10(0.01)^{\mathrm{a}}$ \\
\hline$\alpha^{\mathrm{chl}}$ & $0.056(0.006)^{\mathrm{a}}$ & $0.219(0.063)^{\mathrm{a}}$ & $0.040(0.011)^{\mathrm{a}}$ & $0.028(0.003)^{\mathrm{d}}$ & $0.038(0.004)^{a}$ & $0.026(0.004)^{\mathrm{a}}$ & $0.042(0.005)^{\mathrm{a}}$ & $0.027(0.002)^{\mathrm{b}}$ \\
\hline $\begin{array}{l}\text { Chl a } \\
\left(\text { pg cell }{ }^{-1}\right)\end{array}$ & $1.82(0.45)^{\mathrm{a}}$ & $0.34(0.01)^{\mathrm{b}}$ & $0.83(0.13)^{a}$ & $2.34(0.07)^{\mathrm{b}}$ & $2.17(0.24)^{a}$ & $4.83(0.09)^{b}$ & $1.59(0.19)^{a}$ & $3.64(0.11)^{\mathrm{b}}$ \\
\hline $\begin{array}{l}\text { Cell volume } \\
\left(\mu \mathrm{m}^{-3} \mathrm{cel}^{-1}\right)\end{array}$ & $624.6(3.4)^{\mathrm{a}}$ & $623.8(4.9)^{\mathrm{d}}$ & $570.5(8.1)^{d}$ & $608.5(2.0)^{\mathrm{b}}$ & $582.1(10.1)^{\mathrm{a}}$ & $615.0(7.3)^{\mathrm{a}}$ & $593.1(5.6)^{\mathrm{a}}$ & $640.6(17.5)^{a}$ \\
\hline
\end{tabular}

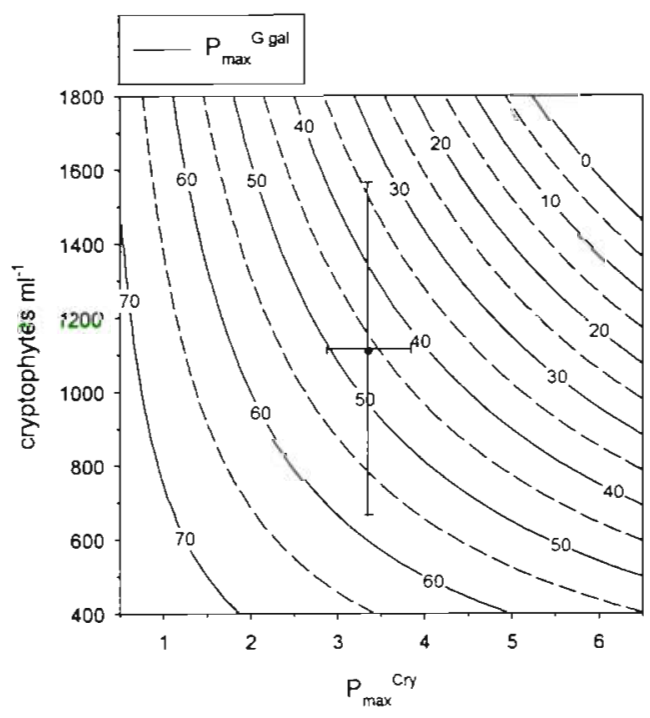

Fig. 3. Results of the sensitivity analysis performed on the correction procedure used to calculate photosynthesis by Gyrodinium galatheanum in samples contaminated by cryptophytes (photosynthesis Expt 2). Contours represent the value of $\mathrm{P}_{\max }{ }^{G g a l}\left(\mathrm{pg} \mathrm{C}\right.$ cell $\left.{ }^{-1} \mathrm{~h}^{-1}\right)$ that computes from the corresponding values of $\mathrm{P}_{\max } C_{r y}$ and cryptophytes cell ${ }^{-1}$ on the $x$ - and $y$-axis, respectively. The mean values of $P_{\max }{ }^{C r y}$ and cryptophytes cell ${ }^{-1}$ were $3.33 \mathrm{pg} \mathrm{C}$ cell $^{-1} \mathrm{~h}^{-1}(\mathrm{n}=3, \mathrm{SD}=0.255)$ and 1118 cryptophytes $\mathrm{ml}^{-1}(\mathrm{n}=3, \mathrm{SD}=230)$, respectively. $(\bullet)$ Value of $P_{\max }{ }^{G, g a l}$ calculated using the mean values of $\mathrm{P}_{\max }{ }^{C r y}$ and cryptophytes cell ${ }^{-1}$. Error bars show the range of $2 \mathrm{SD}$ (standard error) from the mean for both $\mathrm{P}_{\max } \mathrm{Cr}^{\mathrm{C}}$ and cryptophytes cell-1

calculate $G$. galatheanum photosynthesis in samples containing cryptophyte contaminants was robust within a reasonable range of error (2 SD) in the input parameters.
The significant increases ( $t$-test, $p<0.05)$ in the corrected photosynthetic capacity $\left(P_{\max }{ }^{\text {cell }}\right)$ and efficiency $\left(\alpha^{\text {cell }}\right)$ for the second photosynthesis experiment were observed for Gyrodinium galatheanum grown in mixotrophic cultures relative to phototrophic cultures (Fig. 4, Table 3). After feeding on cryptophytes for $24 \mathrm{~h}$, G. galatheanum increased its $\mathrm{P}_{\text {max }}$ cell approximately 2.4-fold compared with that in Defore-feeding samples. A similar magnitude increase in $\alpha^{\text {cell }}$ for after feeding G. galatheanum was also observed (Fig. 4, Table 3). The derived parameter, saturation light intensity $\left(I_{k}\right)$, did not change significantly ( $t$-test, $p=0.057$ ) (Table 3 ).

The photosynthetic rate at an irradiance of $200 \mu \mathrm{mol}$ photons $\mathrm{m}^{-2} \mathrm{~s}^{-1}$ showed an approximate 2 -fold increase in mixotrophic cultures relative to phototrophic cultures in the second photosynthesis experiment (Table 4). Correspondingly, the growth rate and cellular carbon content of Gyrodinium galatheanum grown at this irradiance were approximately 3 - and 2-fold, respectively, higher in mixotrophic cultures than in phototrophic cultures. The mean feeding rate and carbon ingestion rate during the $24 \mathrm{~h}$ feeding incubation were estimated to be 4.95 cryptophytes dinoflagellate $\mathrm{d}^{-1} \mathrm{~d}^{-1}$ and 232.7 pg C dinoflagellate ${ }^{-1} \mathrm{~d}^{-1}$, respectively (Table 4).

\section{DISCUSSION}

Different species of dinoflagellates use different feeding mechanisms for the uptake of food particles, which may result in the uptake of entire food particles or only part of prey cells. For example, some species phagocytize an entire food particle, including the prey cell membrane (i.e. phagotrophy sensu stricto), while others use a peduncle to suck out some of the prey cell 

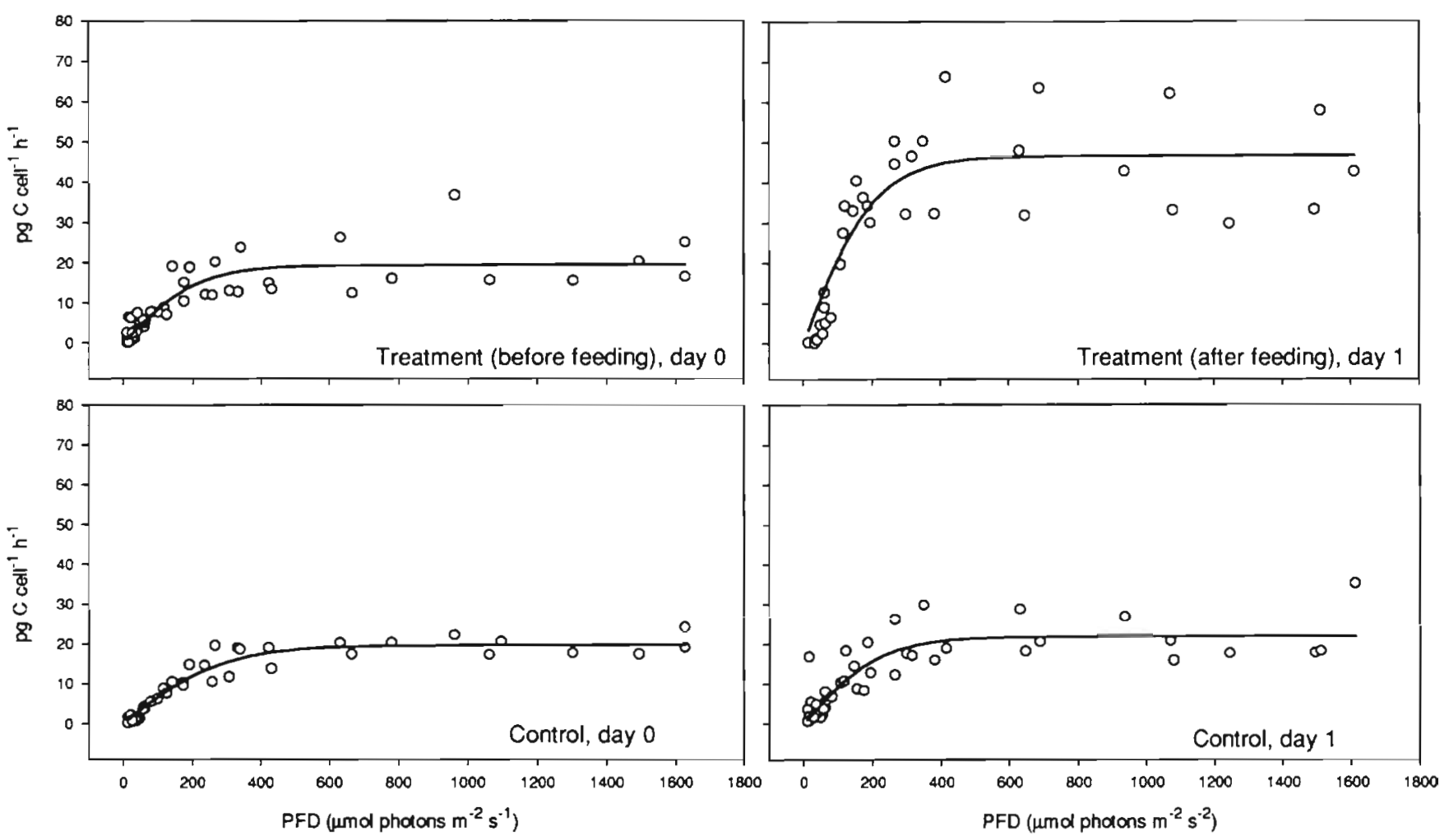

Fig. 4. Gyrodinium galatheanum. Photosynthesis (P) versus irradiance (I) curves for G. galatheanum grown at $200 \mu \mathrm{mol}$ photons $\mathrm{m}^{-2} \mathrm{~s}^{-1}$ in $\mathrm{f} / 2-\mathrm{Si}$ medium (photosynthesis Expt 2). The cryptophycean prey Storeatula major was not fed to G. galatheanum in control bottles at Day 0 and Day 1. In treatment bottles, photosynthesis rates of G. galatheanum were measured before addition of prey (Day 0) and $24 \mathrm{~h}$ after introduction of prey (Day 1). $n=3$. P versus I curves are fit with hyperbolic tangent equation:

$$
\mathrm{P}=\mathrm{P}_{\max }{ }^{\text {cell }} \times \tanh \left(\alpha^{\text {cell }} \times \mathrm{I} / \mathrm{P}_{\max }{ }^{\text {cell }}\right)
$$

Table 3. Photosynthetic parameters of Gyrodinium galatheanum grown phototrophically (control and before addition of prey) and mixotrophically (treatment with addition of prey for $24 \mathrm{~h}$ ) in photosynthesis Expt 2 . Within the same category, having the same letter (a) between the 2 groups indicates there is not a significant difference between these groups ( $t$-test, $p>0.05)$, while having a different letter ( $a$ and $b$ ) between the 2 groups indicates that there is a significant difference $(t$-test, $p<0.05$ ). $n=3$

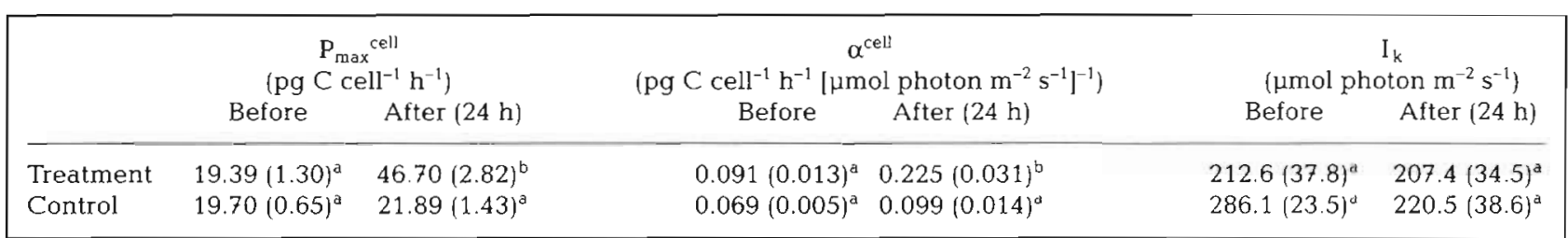

Table 4. Gyrodinium galatheanum. Comparison of physiological attributes in phototrophic (non-feeding) and mixotrophic (feeding) cells growing at an irradiance of $200 \mu \mathrm{mol}$ photons $\mathrm{m}^{-2} \mathrm{~s}^{-1}$ on a $12 \mathrm{~h}$ light:12 h dark cycle (photosynthesis Expt 2). Estimate of carbon ingested by $G$. galatheanum is based on ingestion rate and average cellular carbon content of 47 pg C cell-1 in the prey Storeatula major. "Change is statistically significant $(t$-test, $\mathrm{p}<0.05) . \mathrm{n}=3$

\begin{tabular}{|c|c|c|c|}
\hline & Phototrophic cells & Mixotrophic cells & Percent increased \\
\hline Photosynthetic rate (pg C cell $\left.{ }^{-1} \mathrm{~h}^{-1}\right)$ & $16.1(2.1\}$ & $34.4(3.5)$ & $+114.4^{\circ}$ \\
\hline Growth rate $\left(\mathrm{d}^{-1}\right)$ & $0.23(0.03)$ & $0.66(0.20)$ & $+187.0 \%$ \\
\hline Cellular C (pg cell $\left.{ }^{-1}\right)$ & $198.9(7.9)$ & $402.7(72.7)$ & $+102.5 \%$ \\
\hline Feeding rate (prey cell ${ }^{-1} \mathrm{~d}^{-1}$ ) & - & $4.95(0.78)$ & \\
\hline Ingested $C\left(p g\right.$ cell $\left.{ }^{-1} \mathrm{~d}^{-1}\right)$ & - & 232.7 & \\
\hline
\end{tabular}


contents but leave the plasma membrane outside the predator (i.e. myzocytosis) (Spero 1982, Elbrächter 1991, Wilcox \& Wedemayer 1991, Schnepf \& Elbrächter 1992). Alternatively, some dinoflagellates use a feeding web to surround the prey and digest it outside the cell body of the predator (i.e. pallium feeding) (Jacobson \& Anderson 1986). The mechanism used by Gyrodinium galatheanum when feeding on cryptophytes appears to fit the category of 'phagotrophy sensu stricto' (Schnepf \& Elbrächter 1992). Because entire prey are engulfed, data on instantaneous food vacuole contents and digestion rate can be used to estimate grazing impact on prey populations as well as potential nutritional contributions of feeding to the $C$, $\mathrm{N}$, and P budgets of $G$. galatheanum (Li et al. unpubl.).

The feeding mechanism of Gyrodinium galatheanum resembles that of Peridinium gargantua and Gymnodinium helveticum $f$, achroum. A lobopod-like structure, which is used to capture and engulf prey, has been observed in the latter 2 species (Biecheler 1952, Popovsky 1982). This is in contrast to mixotrophic dinoflagellate species such as Gyrodinium pavillardi, Fragilidium subglobosum and Gyrodinium instriatum, in which the posterior end of the sulcus, rather than a projecting organelle, is used to capture and engulf prey (Biecheler 1952, Skovgaard 1996b, Uchida et al. 1997). We have occasionally observed a thin filament projecting from the extending sulcus region in the epicone of feeding cells of $G$. galatheanum. This species may have a trichocyst-like organelle for assisting in prey capture. Further study, particularly a TEM examination of cells fixed during feeding, would clarify this hypothesis.

HPLC-based pigment analysis was used to trace the pigment dynamics of Gyrodinium galatheanum growing in pure phototrophic and in mixotrophic cultures. Our results for phototrophically grown $G$. galatheanum are similar to those of Johnsen \& Sakshaug (1993), who reported a total of 10 identified chlorophylls and carotenoids that were also present in our samples. However, in our samples we observed 1 unknown pigment and a zeaxanthin which were not reported by Johnsen \& Sakshaug (1993). These differences may be due to the use of different protocols for HPLC analysis or strain differences in $G$. galatheanum. Our isolate was from Chesapeake Bay whereas the Johnsen \& Sakshaug (1993) isolate was from Oslofjord, Norway.

The pigment composition of phototrophically grown Gyrodinium galatheanum has several characteristics that are different from those of most photosynthetic dinoflagellates. For example, peridinin, the most common carotenoid possessed by a majority of phototrophic dinoflagellates (Prezélin 1987), was not found in G. galatheanum (Johnsen \& Sakshaug 1993 and this study). However, this dinoflagellate possesses $\mathrm{chl} c_{3}$, a chlorophyll that is usually found in prymnesiophytes, chrysophyte, and bacillariophytes (Stauber \& Jeffrey 1988, Bidigare 1989, Wright et al. 1991, Millie et al. 1993). The only other dinoflagellate reported to have this unusual pigment composition is Gyrodinium aureolum (Johnsen \& Sakshaug 1993). The possession of $\mathrm{chl} c_{3}$ and carotenoids that are similar to that of prymnesiophytes have led to the hypothesis that these 2 species have prymnesiophycean-derived chloroplasts (Bjornland \& Tangen 1979, Johnsen \& Sakshaug 1993).

In mixotrophic cultures, Gyrodinium galatheanum appears to be capable of retaining for a relatively long period pigments that are derived from the prey Storeatula major. This result is consistent with our previous study, in which we found that ingested cryptophytes were digested by $G$. galatheanum over a relatively long period and that the half-life for food vacuole turnover ranged from $5.68 \mathrm{~h}$ at $29.7^{\circ} \mathrm{C}$ to $138.89 \mathrm{~h}$ at $10^{\circ} \mathrm{C}$. The cryptophycean pigments in mixotrophically grown $G$. galatheanum were probably due to undigested $S$. major prey in food vacuoles, or retention of cryptophycean chloroplasts. Fields \& Rhodes (1991) reported that Gymnodinium acidotum, a freshwater dinoflagellate, retains cryptophycean chloroplasts for at least $10 \mathrm{~d}$ and then digests these chloroplasts. Schnepf et al. (1989) suggested that a blue-green dinoflagellate, Gymnodinium aeruginosum, actually ingests cryptophytes and selectively retains the chloroplasts. It is not clear whether or not $G$. galatheanum retains cryptophycean chloroplasts. Furthermore, the potential benefits of retention of exogenous chloroplasts by a plastid-bearing species such as $G$. galatheanum are unknown. It can be speculated that the pigments in cryptophycean prey (e.g. phycoerythrin and alloxanthin) could be complementary to those in G. galatheanum, and therefore retention of cryptophycean plastids might result in more efficient light absorption by the dinoflagellate in certain light environments.

Growth experiments demonstrate that Gyrodinium galatheanum cannot survive in prolonged darkness even when fed, suggesting that this dinoflagellate is an obligate phototroph and that photosynthesis is essential for its growth. Enhanced growth rates were observed in $G$. galatheanum that were grown in mixotrophic conditions relative to pure phototrophic conditions. Similar enhancements in growth rates were observed in the thecate mixotrophic dinoflagellate Fragilidium subglobosum (Skovgaard 1996a); however, F subglobosum is a facultative mixotroph that is capable of phototrophic growth as well as of strictly heterotrophic growth in the dark. The nutritional strategy used by G. galatheanum is perhaps more similar to the obligately phototrophic chrysophyceans Uroglena americana (Kimura \& Ishida 1985, 1989) and Dinobryon cylindricum (Caron et al. 
1993). A major difference between G. Galatheanum and these chrysophytes, however, is the ability of $G$. galatheanum to grow under strict phototrophic conditions whereas the chrysophytes show no net growth in the absence of prey, possibly as the result of a requirement for growth factor (e.g. phospholipid; Kimura \& Ishida 1989) or photosynthetically derived factors (Caron et al. 1993). Alternatively, the observed inability of G. galatheanum and other obligately phototrophic mixotrophs to grow heterotrophically in the dark, along with its light-stimulated feeding, could be the consequence of the cell's inability to assimilate significant amounts of $\mathrm{C}$ for growth from prey, and a dependence on photosynthesis to meet energy requirement associated with phagotrophy, or reliance on a plastid-derived metabolic factor that is only produced in the light.

Several other mixotrophic dinoflagellates, including Prorocentrum minimum and Ceratium furca, appear to be obligate phototrophs and feeding in these species also appears to be stimulated by light (Stoecker et al. 1997, Smalley pers. comm.). Considering that Gyrodinium galatheanum is an obligate phototroph, it is very likely that changes in photosynthesis associated with mixotrophic growth make an important contribution to the increases in growth rate observed under mixotrophic conditions. The photosynthesis experiments were intended to examine the responses of photosynthetic physiology that are associated with the shift from phototrophic growth to mixotrophic growth. conditions. The rationale behind these studies was that a stimulation of photosynthesis under mixotrophic conditions would be indicative of a major role for phototrophy in feeding cells.

In the second photosynthesis experiment, we measured cell-specific photosynthetic parameters ( $\mathrm{P}_{\max }$ cell and $\alpha^{\text {cell }}$ ) and photosynthetic performance for autotrophic cultures grown in nutrient-replete medium (f/2-Si) at $200 \mu \mathrm{mol}$ photons $\mathrm{m}^{-2} \mathrm{~s}^{-1}$. The values of these parameters were comparable to values published for other similarly sized photosynthetic dinoflagellates (Rivkin \& Seliger 1981, Rivkin \& Voytek 1985, Harding $\&$ Coats 1988). After cultures were shifted from phototrophic to mixotrophic conditions for $24 \mathrm{~h}$, significant increases in $\mathrm{P}_{\max }$ cell, $\alpha^{\text {cell }}$ and photosynthetic performance were observed in Gyrodinium galatheanum. These changes occurred in concert with increases in growth rate that were of similar magnitude to the changes in cell-specific photosynthetic rates. Considering the coincidence of these changes as well as the considerable increases in cellular carbon content and the addition of ingested carbon from prey (Table 4), it can be concluded that both photosynthetic carbon metabolism and phagotrophy play significant roles in supporting the observed increase in growth rate associated with mixotrophy.
The nature of the changes in $P$ versus I curves after feeding can be used to infer the nature of photophysiological changes that occur in association with mixotrophy in Gyrodinium galatheanum acclimated to different nutrient and light environments. In the first experiment, measurement of $\alpha^{\text {cell }}$ and $\alpha^{\text {chl }}$ revealed opposite directional. responses after feeding, with the former increasing and the latter decreasing. This is consistent with synthesis of light harvesting pigments and/or an increase in the 'size' of photosynthetic units (Prezélin 1981, 1987). Increases in cellular chl $a$ in the mixotrophic treatments further support this suggestion. In the second photosynthetic experiment we observed increases in $\alpha^{\text {cell }}$ and $\mathrm{P}_{\max }$ cell associated with mixotrophy. The increase in $\alpha^{\mathrm{crll}}$ is consistent with the first photosynthetic experiment in suggesting that pigment synthesis is a physiological response to mixotrophic conditions. An increase in $P_{\max }{ }^{\text {cell }}$ further suggests an increase in the number or turnover rate of photosynthetic reaction centers (Prezélin 1981, 1987, Falkowski \& Raven 1997), or a change in the relative abundance of RUBISCO per cell or RUBISCO/electron transport components (Sukenik et al. 1987, Orellano \& Perry 1992). The high-light, nutrient-replete treatment from the first experiment is an exception to this pattern. In this treatment we observed a decrease in cellular chl $a_{\text {, }}$ no change in $\alpha^{\text {cell }}$, and a statistically insignificant increase in $\alpha^{\text {chl }}$. This observation is contrary to observations made under the same conditions in the second experiment. An explanation is not readily apparent, although the possibility exists that rapid cell division observed in these cultures $\left(\mu=1.8 \mathrm{~d}^{-1}\right.$ over the $24 \mathrm{~h}$ period) resulted in diluted cellular chl a levels at the time of P-I curve measurement.

As a general rule, photosynthetic performance of phytoplankton at any one irradiance is higher under nutrient-replete than under nutrient-limited conditions for growth. It has been suggested that these increases are due to increases in the amount of nitrogen-containing photosynthetic pigments (Cullen et al. 1992). The physiological responses detected in the first photosynthetic experiment are consistent with the suggestion that Gyrodinium galatheanum eats primarily to obtain nutrients and/or other growth factors (Li et al. unpubl.). However, the observed increases in photosynthetic parameters cannot simply be explained as a result of alleviation of nutrient stress, as the cultures used in the second photosynthetic experiment were growing exponentially in nutrient-replete $\mathrm{f} / 2-\mathrm{Si}$ medium. It is possible, however, that the quality of nutrients used in this study were not optimal or that cell division was limited by lack of prey-derived growth factors (Kimura \& Ishida 1989) and thus that photosynthesis was down regulated in response. 
In nature, growth of phytoplankton is considered to be regulated primarily by light, inorganic nutrients, and temperature (Kirk 1994). In Gyrodinium galatheanum growth appears to be primarily dependent on photosynthesis, although phagotrophy appears to be necessary for optimal photosynthesis and growth. Therefore, conditions under which sufficient light and appropriate prey are available will tend to favor growth of this species. The physiological responses described for $G$. galatheanum under mixotrophic conditions, particularly light-stimulated feeding and increases in photosynthetic efficiency and capacity with feeding, suggest that phagotrophy can improve the cell's ability to utilize high irradiances for growth in nature. These results suggest that phagotrophy contributes indirectly to $G$. galatheanum's ability to grow rapidly, by enhancing its photosynthetic performance, as well as directly, by supplying organic sources of $C_{\text {, }}$ $N$, and $P$ for growth and metabolism.

Acknowledgements. We thank Laurie Van Heukelem for HPLC sample analysis and her constructive suggestions in interpreting pigment results. We thank D. Wayne Coats for the use of video equipment. Discussion with D. Wayne Coats, Larry W. Harding Jr and Per Juel Hansen contributed to the improvement of this manuscript. Alf Skovgaard kindly provided the computer program for calculation of ingestion rate. This work was supported by US National Science Foundation grant no. OCE931772 awarded jointly to D. Wayne Coats and D.K.S. This is contribution number 3158 from the University of Maryland Center for Environmental Studies.

\section{LITERATURE CITED}

Andersson A, Falk S, Samuelsson G, Hagström § (1989) Nutritional characteristics of a mixotrophic nanoflagellate, Ochromonas sp. Microbiol Ecol 17:251-262

Banse K (1982) Cell volumes, maximal growth rates of unicellular algae and ciliates, and the role of ciliates in marine pelagial. Limnol Oceanogr 27:1059-1071

Bidigare RR (1989) Photosynthetic pigment composition of the brown tide alga: unique chlorophyll and carotenoid derivatives. In: Cosper EM, Bricelj VM, Carpenter EJ (eds) Novel phytoplankton blooms. Springer-Verlag, Berlin, p $57-75$

Biecheler B (1952) Recherches sur les Peridiniens. Bull Biol Fr Belg Suppl 36:1-149

Bjornland T, Tangen K (1979) Pigmentation and morphology of a marine Gyrodinium (Dinophyceae) with a major carotenoid different from peridinin and fucoxanthin J Phycol 15:457-463

Caron DA, Sanders RW, Lim EL, Marras $\varnothing \mathrm{C}$, Amaral LA Whitney S, Aoki RB, Porter KG (1993) Light-dependent phagotrophy in the freshwater mixotrophic chrysophyte Dinobryon cylindricum. Microbiol Ecol 25:93-111

Chan A (1980) Comparative physiological study of marine diatoms and dinoflagellates in relation to irradiance and cell size. II. Relationship between photosynthesis, growth and carbon/chlorophyll a ratio. J Phycol 16:428-432

Cullen JJ, Yang XL, MacIntyre HL (1992) Nutrient limitation of marine photosynthesis. In: Falkowski PG, Woodhead
AD (eds) Primary productivity and biogeochemical cycles in the sea. Plerum Press, New York, p 69-88

Elbrächter ME (1991) Food uptake mechanisms in phagotrophic dinoflagellates and classification. In: Patterson DJ, Larsen J (eds) The biology of free-living heterotrophic flagellates. Systematics Association Special Volume No. 45. Clarendon Press, Oxford, p 303-314

Falkowski PG, Raven JA (1997) Photosynthesis in continuous light. In: Falkowski PG, Raven JA (eds) Aquatic photosynthesis. Blackwell Science, Inc, Malden, MA, p 193-227

Fields SD, Rhodes RG (1991) Ingestion and retention of Chroomonas spp. (Cryptophyceae) by Gymnodinium acidotum (Dinophyceae). J Phycol 27:525-529

Gaines G, Elbrächter M (1987) Heterotrophic nutrition. In: Taylor FJR (ed) The biology of dinoflagellates. Blackwell Scientific Publications, Oxford, p 224-268

Granéli E, Carlsson P (1998) The ecological significance of phagotrophy in photosynthetic flagellates. In: Anderson DM, Cembella AD, Hallegraeff GM (eds) Physiological ecology of harmful algal blooms. NATO ASI Series 41:539-557

Guillard RRL (1979) Culture of phytoplankton for feeding marine invertebrates. In: Smith WL, Chanley $\mathrm{MH}$ (eds) Culture of marine invertebrate animals. Plenum Publishing Corp, New York, p 29-60

Hansen PJ (1998) Phagotrophic mechanisms and prey selection in mixotrophic phytoflagellates. In: Anderson DM, Cembella AD, Hallegraeff GM (eds) Physiological ecology of harmful algal blooms. NATO ASI Series 41:525-5.37

Hansen PJ, Nielsen TG (1997) Mixotrophic feeding of Fragilidium subglobosum (Dinophyceae) on three species of Ceratium: effects of prey concentration, prey species and light intensity. Mar Ecol Prog Ser 147:187-196

Harding LW Jr, Coats DW (1988) Photosynthetic physiology of Prorocentrum mariae-lebouriae (Dinophyceae) during its subpycnocline transport in Chesapeake Bay. J Phycol 24: $77-89$

Jacobson DMI, Anderson DM (1986) Thecate heterotrophic dinoflagellates: feeding behavior and mechanisms. J Phy$\operatorname{col} 22: 249-258$

Jassby AD, Platt T (1976) Mathematical formulation of the relationship between photosynthesis and light for phytoplankton. Limnol Oceanogr 21:540-547

Johnsen G, Sakshaug E (1993) Bio-optical characteristics and photoadaptive responses in the toxic and bloom-forming dinoflagellates Gyrodinium aureolum, Gymnodinium galatheanum, and two strains of Prorocentrum minimum. J Phycol 29:627-642

Kimura B, Ishida Y (1985) Photophagotrophy in Uroglena americana, Chrysophyceae. Jpn J Limnol 46:315-318

Kimura B, Ishida Y (1989) Phospholipid as a growth factor of Uroglena americana, a red tide Chrysophyceae in Lake Biwa. Nippon Suisan Gakkaishi 55:799-804

Kirk JT (1994) Photosynthesis in the aquatic environment. In: Kirk JT (ed) Light and photosynthesis in aquatic ecosystems. Cambridge University Press, Cambridge, p 314-359

Lewis MR, Smith JC (1983) A small volume, short-incubationtime method for measurement of photosynthesis as a function of incident irradiance. Mar Ecol Prog Ser 13:99-102

Li A, Stoecker DK, Coats DW, Adam EJ (1996) Ingestion of fluorescently labeled and phycoerythrin-containing prey by mixotrophic dinoflagellates. Aquat Microb Ecol 10; 139-147

Millie DF, Paerl HW, Hurley JP (1993) Microalgal pigment assessments using high-performance liquid chromatography: a synopsis of organismal and ecological applications. Can J Fish Aquat Sci 50:2513-2527

Orellano MV, Perry MJ (1992) An immunoprobe to measure 
Rubisco concentrations and maximal photosynthetic rates of individual phytoplankton cells. Limnol Oceanogr 37 : $478-490$

Parsons TR, Maita Y, Lalli CM (1984) A manual of chemical and biological methods for seawater analysis. Pergamon Press Inc, New York

Popovsky J (1982) Another case of phagotrophy by Gymnodinium helveticum $f$. achroum Skuja. Arch Protistenkd 125:73-78

Prezélin BB (1981) Light reactions in photosynthesis. In: Platt $T$ (ed) Physiological bases of phytoplankton ecology. Can Bull Fish Aquat Sci, p 210 -346

Prezélin BB (1987) Photosynthetic physiology of dinoflagellates. In: Taylor FJR (ed) The biology of dinoflagellates. Blackwell Scientific Publications, Oxford, p 174-223

Raven JA (1984) Energetics and transport in aquatic plants. Alan R Liss Inc, New York, p 253-317

Rivkin RB, Seliger HH (1981) Liquid scintillation counting for ${ }^{14} \mathrm{C}$ uptake of single algal cells isolated from natural samples. Limnol Oceanogr 26:780-785

Rivkin RB, Voytek MA (1985) Photoadaptations of photosynthesis by dinoflagellates from natural populations: a species approach. In: Anderson DM, White AW, Baden DG (eds) Toxic dinoflagellates. Elsevier Science Publishing Co, Inc, New York, p 97-102

Schnepf $E$, Elbrächter $M$ (1992) Nutritional strategies in dinoflagellates: a review with emphasis on cell biological aspects. Eur J Protistol 28:3-24

Schnepf E, Winter S, Mollenhauer D (1989) Gymnodinium aeruginosum (Dinophyta): a blue-green dinoflagellate with a vestigial, anucleate, cryptophycean endosymbiont. Plant Syst Evol 164:75-91

Skovgaard A (1996a) Mixotrophy in Fragilidium subglobosum (Dinophyceae): growth and grazing responses as functions of light intensity. Mar Ecol Prog Ser 143:247-253

Skovgaard A (1996b) Engulfment of Ceratium spp. (Dino-

Editorial responsibility: John Dolan,

Villefranche-sur-Mer, France phyceae) by the thecate photosynthetic dinoflagellate Fragilidium subglobosum. Phycologia 36:490-499

Spero HJ (1982) Phagotrophy in Gymnodinium fungiforme (Pyrrhophyta): the peduncle as an organelle of ingestion. J Phycol 18:356-360

Stauber JL, Jeffrey SW (1988) Photosynthetic pigments in fifty-one species of marine diatoms. J Phycol 24:158-172

Stoecker DK, Li A, Coats DW, Gustafson D, Nannen MK (1997) Mixotrophy in the dinoflagellate Prorocentrum minimum. Mar Ecol Prog Ser 152:1-12

Sukenik A, Bennett J, Falkowski P (1987) Light-saturated photosynthesis - limitation by electron transport or carbon fixation? Biochim Biophys Acta 891:205-215

Tang EPY (1995) The allometry of algal growth rates. J Plankton Res 17:1325-1335

Tang EPY (1996) Why do dinoflagellates have lower growth rates? J Phycol 32:80-84

Uchida T, Kamiyama T, Matsuyama Y (1997) Predation by a photosynthetic dinoflagellate Gyrodinium instratum on loricated ciliates. J Plankton Res 19:603-608

Van Heukelem L, Lewitus AJ, Kana TM, Craft NE (1992) High-performance liquid chromatography of phytoplankton pigments using a polymeric reversed-phase $\mathrm{C} 18 \mathrm{col}-$ umn. J Phycol 28:867-872

Van Heukelem L, Lewitus AJ, Kana TM, Craft NE (1994) Improved separations of phytoplankton pigments using temperature-controlled high performance liquid chromatography. Mar Ecol Prog Ser 114:303-313

Wilcox LW, Wedemayer GJ (1991) Phagotrophy in the freshwater, photosynthetic dinoflagellate Amphidinium cryophilum. J Phycol 27:600-609

Wright SW, Jeffrey SW, Mantoura RFC, Llewellyn CA, Bjornland T, Repeta D, Welschmeyer N (1991) An improved HPLC method for the analysis of chlorophyll and carotenoids from marine phytoplankton. Mar Ecol Prog Ser 77:183-196

Submitted: October 26, 1998; Accepted: March 4, 1999

Proofs received from author(s): September 24, 1999 